\title{
SISTEM PENDUKUNG KEPUTUSAN UNTUK KELAYAKAN PEMBERIAN KREDIT DENGAN METODE FUZZY TSUKAMOTO (STUDI KASUS KOPERASI KEMUNING PERSADA CABANG BANDUNG)
}

\author{
Sri Kurniasih ${ }^{1}$, Lovita Sari Br Ginting ${ }^{2}$ \\ Konsentrasi Sistem Informasi, Program Studi Sistem Informasi, Politeknik Komputer Niaga LPKIA \\ Jl. Soekarno Hatta No. 456 Bandung 40266, Telp. +6222-75642823, Fax. +6222-7564282 \\ ${ }^{1}$ sri.kurniasih@yahoo.co.id ${ }^{2}$ lovitasbg@gmail.com
}

Koperasi Kemuning Persada (KKP) merupakan salah satu perusahaan yang bergerak dibidang jasa pemberian kredit, dimana tugas utama KKP harus mempertimbangkan besar/kecilnya pinjaman yang akan diberikan kepada para calon nasabahnya. Seringkali terjadi kesalahan dalam pemberian pinjaman yang diberikan kepada calon nasabah karena penilaian yang dijadikan parameter tidak objekti, terutama dalam hal penentuan nilai besar kecilnya besaran pinjaman kredit yang di ajukan, hal ini mengakibatkan beberapa permasalahan dalam hal keputusan yang harus diambil oleh kepala cabang terkait. Oleh karena itu perlu adanya alat atau sistem yang dapat membantu dalam hal pengambilan keputusan kepala cabang, terkait dengan besar/kecil pinjaman yang diberikan. Metode yang digunakan peneliti dalam merancang Sistem Pendukung Keputusan ini adalah metode Fuzzy Tsukamoto, dimana parameter yang dijadikan kriteria dalam pemberian kredit digolongkan kedalam 3 (tiga) hal yaitu penghasilan, jaminan serta lama usaha. Sedangkan pendekatan penelitian dalam perancangan sistem ini menggunakan metodelogi Berorientasi Obyek, di bantu dengan pengumpulan data menggunakan metode wawancara dan observasi. Beberapa Tools yang digunakan Untuk menganalisis proses bisnisnya dan kebutuhan fungsionalnya menggunakan tools dari Unified Modelling Language (UML), diantaranya Usecase diagram, Sequece Diagram, Class Diagram, Activity Diagram. Aplikasi yang peneliti rancang berbasis web dengan menggunakan Framework CodeIgniter, pemrograman aplikasi menggunakan PHP dan HTML sedang perancangan database menggunakan MySQL.

Kata kunci : SPK, Kredit, Fuzzy Tsukamoto

Koperasi Kemuning Persada (KKP) is one of the companies engaged in lending services, where the main task of the KKP must consider the size of the loan to be given to prospective customers. There is often an error in granting loans to prospective customers because the valuation used is not an objective parameter, especially in terms of determining the size of the proposed loan size, it causes several problems in terms of decisions that must be taken by the relevant branch head. Therefore it is necessary to have a tool or system that can help in terms of decision making of the branch head, related to large / small loans granted. The method used by researchers in designing this Decision Support System is the Fuzzy Tsukamoto method, where the parameters used as criteria in granting credit into 3 (three) things, namely income, collateral and length of business. While the research approach in designing this system uses Object Oriented methodology, assisted with data collection using interview and observation methods. Some tools used to analyze business processes and functional requirements use tools from the Unified Modeling Language (UML), including Usecase diagrams, Sequence Diagrams, Class Diagrams, Activity Diagrams. Applications that researchers design are web-based using the CodeIgniter Framework, programming language uses PHP and HTML while database design uses MYSQL.

Keywords: SPK, Credit, Fuzzy Tsukamoto

\section{Pendahuluan}

\subsection{Latar Belakang Masalah}

Koperasi simpan pinjam atau biasa disebut koperasi kredit merupakan suatu lembaga keuangan bukan bank yang memberikan pelayanan kepada masyarakat, baik itu berupa pinjaman ataupun tempat penyimpanan uang untuk masyarakat. Koperasi yang ada di Indonesia memiliki kegiatan utama yaitu menyediakan jasa penyimpanan dan pinjaman dana kepada nasabah koperasi 
dengan tujuan memajukan kesejahteraan nasabah.

Koperasi Kemuning Persada (KKP) merupakan salah satu perusahaan yang bergerak di bidang jasa kredit, yang memiliki jumlah nasabah kurang lebih 1000 orang. Koperasi ini memberikan kredit kepada nasabah dan koperasi ini hanya memberikan kredit kepada nasabah yang memiliki usaha/wirausaha, Namun pada KKP merasa kesulitan dalam pengambilan keputusan karena beberapa pinjaman terkadang tidak objektif dalam penentuan besar/kecilnya kredit, hal ini disebabkan karena jumlah nasabah/calon nasabah yang mengajukan pinjaman sangat banyak dan setiap nasabah memiliki kriteria yang berbedabeda. Kesulitan lain pihak koperasi masih menggunakan cara sederahana dalam menghitung parameter kredit sehingga perhitungan data secara manual ini membutuhkan waktu yang lama dan berdampak pada lamanya waktu yang dibutuhkan dalam pengambilan keputusan. Resiko yang dihadapi koperasi cukup besar, karena acuan data tidak akurat, perhitungan yang lambat dan tidak terkontrol nya data nasabah yang berakibat terhadap banyaknya pinjaman yang menunggak (kredit Macet), bahkan kegagalan pembayaran pinjaman (Anggota Kabur).

Untuk membantu mengatasi masalah yang terjadi, dibutuhkan sebuah sistem berbasisi komputer yang dapat mengontrol kesediaan data dan keakuratan data pengajuan pinjaman nasabah, serta sehingga penilaian terhadap nasabah dari parameter persyaratan dapat dengan mudah di kelola dan memberikan dampak yang cepat terhadap pendukung keputusan. SPK yang di usulkan haruslah berbasis komputer, karena hal ini sangat penting, mengingat dimana hampir sebagian besar koperasi yang ada di indonesia masih belum mengetahui beberapa
p-ISSN : 1858-3911, e-ISSN : 2614-5405

https://journal.uniku.ac.id/index.php/ilkom

metode yang dapat mempercepat dan membantu pekerjaan dalam menyelesaikan dalam mengoperasikan pinjaman kepada calon nasabah.

Analisa proses bisnis yang berjalan dalam melengkapi kebutuhan data dan sistem yang akan dirancang, peneliti menggunakan analisa SWOT untuk mengetahui apa saja kekuatan (Strengths), kelemahan (Weakness), ancaman (Opportunities) serta peluang (Threats) dari lingkungan internal dan eksternal perusahaan. Sedangkan perhitungan data dalam SPK menggunakan metode Fuzzy Tsukamoto sebagai penunjang sistem/pemecahan masalah yang diharapkan dapat membantu untuk pencarian sebuah solusi yang tepat. Di dalam metode Fuzzy Tsukamoto terdapat proses defuzifikasi dimana dapat menghasilkan hasil akhir sesuai dengan rule atau aturan yang tersedia di dalamnya.(Thamrin, 2012).

\subsection{Identifikasi Permasalahan}

Berdasarkan uraian latar belakang masalah yang telah tertulis di atas, dapat di identifikasi masalah yang akan dijadikan bahan penelitian yaitu:

1. Belum adanya aplikasi yang dapat menghitung dengan cepat kriteria debitur (parameter kriteria peminjaman) secara otomatis, sehingga penentuan kisaran pinjaman (besar/kecilnya) pemberian kredit kepada calon nasabah menjadi sangat lamban.

2. Koperasi Membutuhkan waktu yang lama untuk memberikan keputusan kepada nasabah karena kriteria setiap nasabah berbeda-beda dan data masih dalam bentuk dokumen.

\subsection{Ruang Lingkup Permasalahan}

1. SPK ini hanya sebagai alat bantu bagi pihak KKP dalam menentukan berapa besar/kecilnya pinjaman yang akan diberikan kepada calon nasabah 
dengan kriteria: Penghasilan Perhari, Lama Berdirinya Usaha dan Nominal Jaminan

2. Prosedur dalam SPK ini untuk menentukan kisaran pinjaman (besar/kecilnya) kredit yang akan diberikan kepada calon nasabah dimulai dari penginputan data pinjaman sampai dengan persetujuan kredit.

3. Belum adanya dokumentasi data secara komputerisasi yang mengakibatkan perhitungan parameter terhadap pin jaman menjadi lambat.

\subsection{Tujuan Perancangan}

1. Merancang SPK untuk membantu koperasi kemuning persada menggunakan metode Fuzzy Tsukamoto.

2. Untuk membantu/mempemudah Koperasi dalam menentukan kelayakan pemberian kredit terhadap nasabah dengan menggunakan SPK

3. Pemenuhan kebutuhan informasi tentang pemberian kredit akan didapatkan secara cepat dan terstruktur dibantu dengan penyimpanan data menggunakan sistem database.

\section{Landasan Teori}

\subsection{Sistem Pendukung Keputusan}

Sistem pendukung keputusan sebagai sistem berbasis komputer yang terdiri dari tiga komponen yang saling berinteraksi, sistem bahasa (mekanisme untuk memberikan komunikasi antara pengguna dan komponen sistem pendukung keputusan lain), sistem pengetahuan (respositori pengetahuan domain masalah yang ada pada sistem pendukung keputusan atau sebagai data atau sebagai prosedur), dan sistem pemrosesan masalah (hubungan antara dua komponen lainnya, terdiri dari satu atau lebih kapabilitas manipulasi
p-ISSN : 1858-3911, e-ISSN : 2614-5405

https://journal.uniku.ac.id/index.php/ilkom

masalah umum yang diperlukan untuk pengambilan keputusan). [1]

\subsection{Kredit}

Menurut Jopie Jusuf dalam bukunya yang berjudul "Analisis Kredit Untuk Account Officer" Kredit adalah kemampuan untuk melaksanakan suatu pembelian atau mengadakan suatu pinjaman dengan suatu janji, pembayaran akan dilaksanakan pada jangka waktu yang telah disepakati. [2]

\subsection{Koperasi}

Koperasi adalah badan usaha yang mengorganisir pemanfaatan dan pendayagunaan sumber daya ekonomi para anggotanya atas dasar prinsip prinsip koperasi dan kaidah usaha ekonomi untuk meningkatkan taraf hidup anggota pada khususnya dan masyarakat daerah pada umumnya, dengan demikian koperasi merupakan ekonomi rakyat dan sokoguru perekonomian nasional. [3]

\subsection{Logika fuzzy}

[4] Logika fuzzy merupakan salah satu komponen pembentuk soft computing. dasar logika fuzzy adalah teori himpunan fuzzy yang peranan derajat keanggotaannya sebagai penentu keberadaan elemen dalah suatu himpunan sangatlah penting.

[4] menyatakan bahwa pada himpunan tegas (crisp), nilai keanggotaan suatu item $x$ dalam suatu himpunan $\mathrm{A}$, yang sering ditulis dengan $\mu_{\mathrm{A}}[x]$, memiliki 2 kemungkinan yaitu:

1. Satu (1), yang berarti bahwa suatu item menjadi anggota dalam suatu himpunan, atau

2. Nol (0), yang berarti bahwa suatu item tidak menjadi anggota dalam suatu himpunan.

\subsection{Tsukamoto}


[4] Pada metode Tsukamoto, setiap konsekuen pada aturan berbentuk $I F$ THEN harus direpresentasikan dengan suatu himpunan fuzzy dengan fungsi keanggotaan monoton. Sebagai hasilnya, output hasil inferensi dari tiap-tiap aturan diberikan dengan tegas (crisp) berdasarkan $\alpha$-predikat (fire strength). Hasil akhirnya diperoleh dengan menggunakan rata-rata terbobot.

\section{Analisis dan Perancangan}

\subsection{Aliran Proses}

Dalam sub-bab ini dijelaskan prosesproses dalam Perangkat Lunak yang dimodelkan dalam sekumpulan use case dan actor serta hubungannya yang digambarkan dalam diagram use case.

\subsubsection{Usecase Diagram}

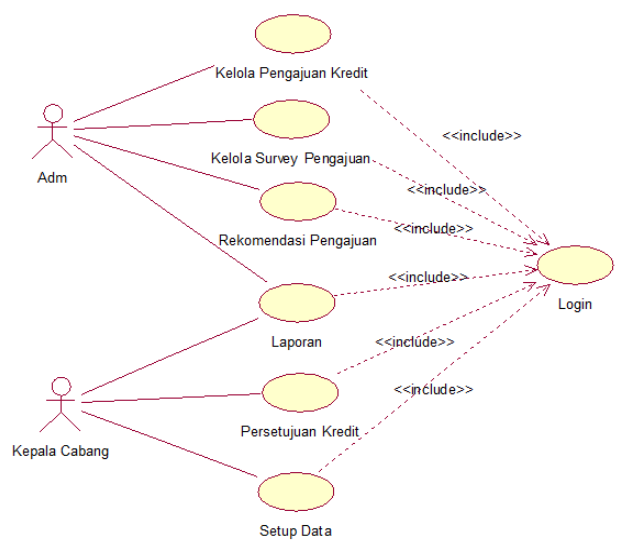

Gambar3.1 Use Case Diagram

\subsection{Activity Diagram}

Aktivitas dan operasi yang ada dalam Perangkat Lunak, dimodelkan dalam activity diagram yang disertai uraian tekstual (uraian workflow). Berikut ini adalah salah satu dari activity diagram yang terkait dengan use case.
p-ISSN : 1858-3911, e-ISSN : 2614-5405

https://journal.uniku.ac.id/index.php/ilkom

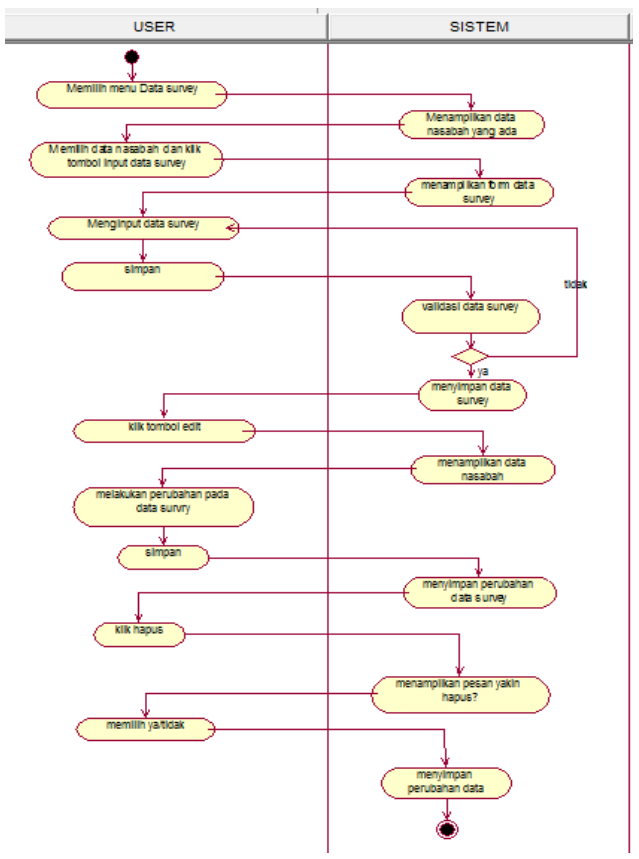

Gambar 3.2 Activity Diagram Kelola Data Pengajuan

\subsection{Sequence Diagram}

sequence diagram merupakan diagram aktivitas yang mengacu kepada fungsionalitas yang terdapat pada use case diagram. Berikut ini adalah salah satu sequence diagram

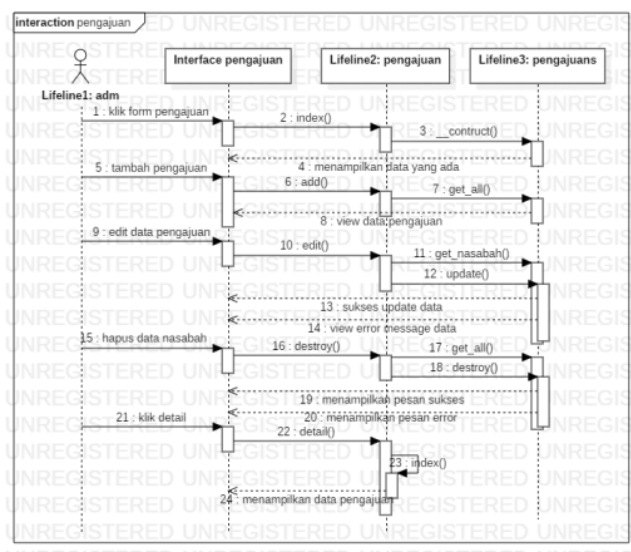

Gambar 3.3 Sequence Diagram pengajuan kredit

\section{Implementasi}

\subsection{Penjadwalan Rencana Kegiatan}


JURNAL NUANSA INFORMATIKA

Volume 14 Nomor 1, Januari 2020

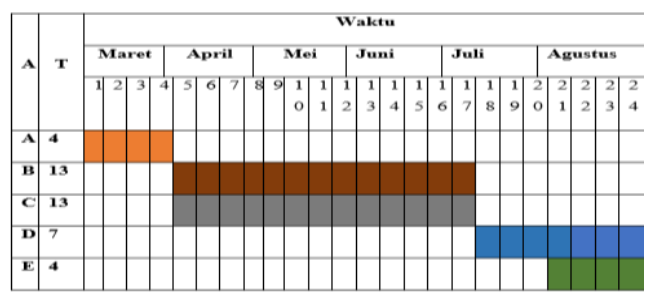

Gambar 4.1 Jadwal Pembuatan

Aplikasi

\section{Keterangan:}

A (Aktivitas) : Nama Aktivitas T (Time) : Waktu yang diperlukan untuk menyelesaikan aktivitas

\subsection{Implemetasi Antarmuka}

Sub bab ini memperlihatkan hasil dari implementasi yang telah dilakukan. Hasil implementasi ini diperlihatkan per dialog screen.

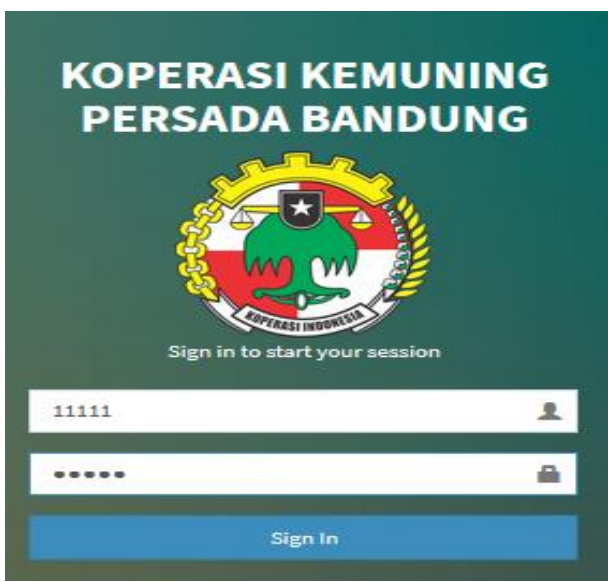

Gambar 4.2 Dialog screen Tampilan Login

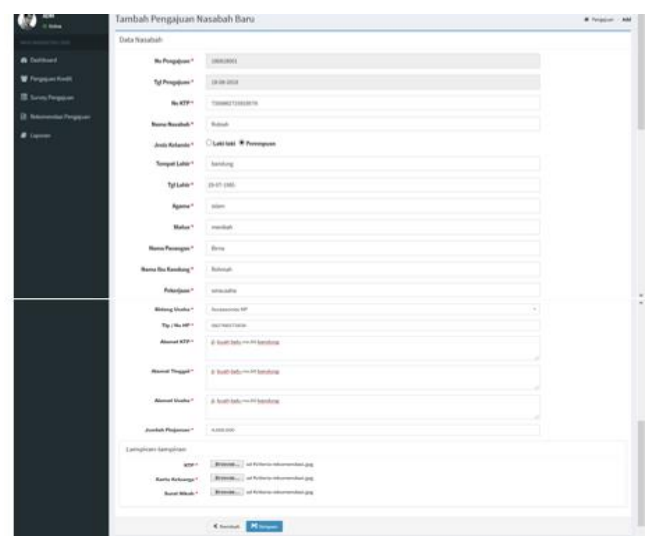

p-ISSN : 1858-3911, e-ISSN : 2614-5405

https://journal.uniku.ac.id/index.php/ilkom

Gambar 4.3 Dialog screen Antarmuka Pengajuan Kredit

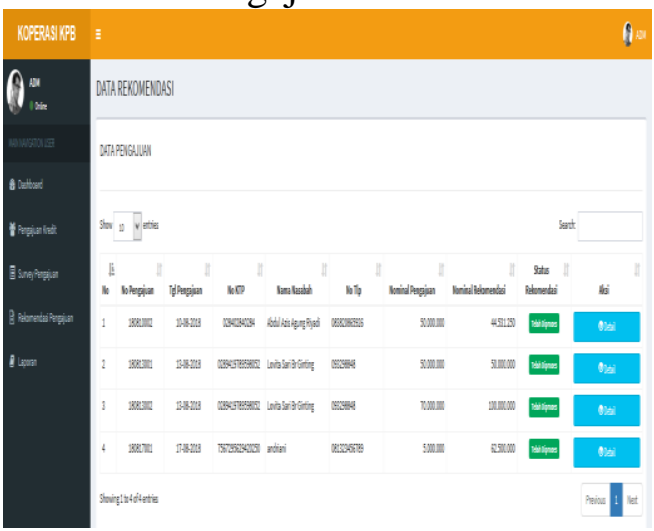

Gambar 4.4 Dialog screen Form

Rekomendasi Pengajuan

\subsection{Himpunan Fuzzy Tsukamoto}

\begin{tabular}{|c|c|c|c|c|}
\hline Fungsi & Kriteria & $\begin{array}{l}\text { Himpunan } \\
\text { Fuzzy }\end{array}$ & $\begin{array}{l}\text { Semesta } \\
\text { Pembicara }\end{array}$ & Domain \\
\hline \multirow{13}{*}{ Input } & \multirow[t]{5}{*}{ Penghasilan } & $\begin{array}{l}\text { Sangat } \\
\text { kurang }\end{array}$ & \multirow{5}{*}{$\begin{array}{l}{[200 \mathrm{rb}} \\
1.1 \mathrm{jt}]\end{array}$} & $\begin{array}{l}{[300 \mathrm{rb}} \\
400 \mathrm{rb}]\end{array}$ \\
\hline & & Kurang & & $\begin{array}{l}{[300 \mathrm{rb}} \\
400 \mathrm{rb} \\
600000]\end{array}$ \\
\hline & & Cukup & & $\begin{array}{l}\text { [400rb } \\
600 \mathrm{rb} \\
800 \mathrm{rb}]\end{array}$ \\
\hline & & Baik & & $\begin{array}{l}{[600 \mathrm{rb}} \\
800 \mathrm{rb} \\
1 \mathrm{jt}]\end{array}$ \\
\hline & & $\begin{array}{l}\text { Sangat } \\
\text { Baik }\end{array}$ & & $\begin{array}{l}{[800 \mathrm{rb}} \\
1 \mathrm{jt}]\end{array}$ \\
\hline & \multirow[t]{3}{*}{$\begin{array}{l}\text { Lama } \\
\text { Usaha }\end{array}$} & Kurang & \multirow[t]{3}{*}[\begin{array}{ll}{0}&{6}\end{array}]{} & {$\left[\begin{array}{ll}1 & 3\end{array}\right]$} \\
\hline & & Cukup & & {$\left[\begin{array}{lll}1 & 3 & 5\end{array}\right]$} \\
\hline & & $\begin{array}{l}\text { Sangat } \\
\text { Baik }\end{array}$ & & [3 5] \\
\hline & \multirow[t]{5}{*}{ Jaminan } & $\begin{array}{l}\text { Sangat } \\
\text { Kurang }\end{array}$ & \multirow[t]{5}{*}{$\begin{array}{l}{[200 \mathrm{rb}} \\
1.1 \mathrm{jt}]\end{array}$} & $\begin{array}{l}300 \mathrm{rb} \\
400 \mathrm{rb}] \\
\end{array}$ \\
\hline & & Kurang & & $\begin{array}{l}300 \mathrm{rb} \\
400 \mathrm{rb} \\
500 \mathrm{rb}]\end{array}$ \\
\hline & & Cukup & & $\begin{array}{l}{[400 \mathrm{rb}} \\
500 \mathrm{rb} \\
800 \mathrm{rb}]\end{array}$ \\
\hline & & Baik & & $\begin{array}{l}500 \mathrm{rb} \\
800 \mathrm{rb} \\
1 \mathrm{jt}]\end{array}$ \\
\hline & & $\begin{array}{l}\text { Sangat } \\
\text { Baik }\end{array}$ & & $\begin{array}{l}{[800 \mathrm{rb}} \\
1 \mathrm{jt}]\end{array}$ \\
\hline \multirow[t]{3}{*}{ Output } & \multirow[t]{3}{*}{ Pinjaman } & Sedikit & \multirow[t]{3}{*}{ [1jt 20jt] } & $\begin{array}{l}1 \mathrm{jt} \\
10 \mathrm{jt}]\end{array}$ \\
\hline & & Sedang & & $\begin{array}{l}{[1 \mathrm{jt} 10 \mathrm{jt}} \\
20 \mathrm{jt}]\end{array}$ \\
\hline & & Banyak & & $\begin{array}{l}{[10 \mathrm{jt}} \\
20 \mathrm{jt}]\end{array}$ \\
\hline
\end{tabular}


Pada pengujian tahapan tsukamoto digunakan data pengajuan atas nama Abdul Azis Agung Riyadi dengan pendapatan Rp 600.000, lama usaha 3 tahun, serta jaminan Rp 55.000.000.

Berikut perhitungannya

\section{A. Fuzzyfikasi}

1. Penghasilan

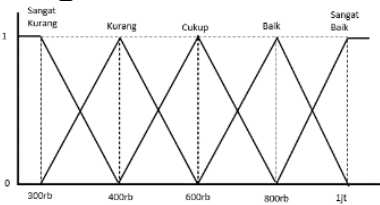

Derajat Keanggotaan Sangat Kurang: $\mu$ Phasil s. kurang $[X]=\{$

Derajat Keanggotaan Kurang: $\mu$ Phasil kurang $[X]$

$=\left\{\begin{array}{l}\frac{x-300.000}{0} ; x \leq 300.000 \text { atau } x \geq 600.000 \\ \frac{400.000-300.000}{\frac{600.000-x}{600.000-400.000} ;} ; 00.000 \leq x \leq 400.000\end{array}\right.$

Derajat Keanggotaan Cukup:

$\mu$ Phasil Cukup $[X]$

$=\left\{\begin{array}{l}0 ; x \leq 400.000 \text { atau } x \geq 800.000 \\ \frac{x-400.000}{600.000-400.000} ; 400.000 \leq x \leq 600.000 \\ \frac{800.000-x}{800.000-600.000} ; 600.000 \leq x \leq 800.000\end{array}\right.$

Derajat Keanggotaan Baik: $\mu$ Phasil Baik $[X]$

$=\left\{\begin{array}{l}0 ; x \leq 600.000 \text { atau } x \geq 1000.000 \\ \frac{x-600.000}{800.000-600.000} ; 600.000 \leq x \leq 800.000 \\ \frac{1000.000-x}{1000.000-800.000} ; 800.000 \leq x \leq 1000.000\end{array}\right.$

Derajat Keanggotaan Sangat Baik: $\mu$ Phasil SangatBaik $[X]$

$=\left\{\begin{aligned} 0 & ; x \leq 800.000 \\ \frac{x-800.000}{1.000 .000-800.000} ; & ; 00.000<x<1.000 .000 \\ 1 ; & x \geq 1.000 .000\end{aligned}\right.$

Nilai Keanggotaan Penghasilan Abdul Azis:

a. Phasil skurang $(625.000)=0$

b. Phasil kurang $(625.000)=0$

c. Phasil Cukup(625.000) = $(800.000-625.000) /(800.000-$ $600.000)$

$=0.875$
p-ISSN : 1858-3911, e-ISSN : 2614-5405

https://journal.uniku.ac.id/index.php/ilkom

d. Phasil Baik $(625.000)=(625.000$

$-600.000) /(800.000-600.000)$

$=0.125$

e. Phail SangatBaik $(625.000)=0$;

2. Lama usaha

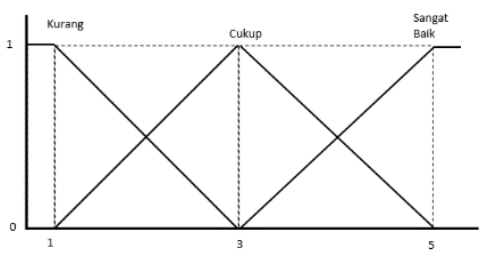

Derajat Keanggotaan Kurang:

$$
\mu \text { Pusaha kurang }[X]=\left\{\begin{array}{r}
1 ; x \leq 1 \\
\frac{3-x}{3-1} ; 1<x<3 \\
0 ; x \geq 3
\end{array}\right.
$$

Derajat Keanggotaan cukup:

$$
\mu \text { Pusaha cukup }[X]=\left\{\begin{array}{l}
0 ; x \leq 1 \text { atau } x \geq 3 \\
\frac{x-1}{3-1} ; 1 \leq x \leq 3 \\
\frac{5-x}{5-3} ; 3 \leq x \leq 5
\end{array}\right.
$$

Derajat Keanggotaan Sangat Baik:

$$
\mu \text { Pusaha SangatBaik }[X]=\left\{\begin{array}{r}
0 ; x \leq 3 \\
\frac{x-3}{5-3}, 3<x<5 \\
1 ; x \geq 5
\end{array}\right.
$$

Nilai keanggotaan Lama Usaha Abdul Azis Agung Riyadi:

a. Pusaha kurang $(3)=0$

b. $\operatorname{Pusaha} \operatorname{cukup}(3)=1$

Pusaha SangatBaik(3) = 0aminan

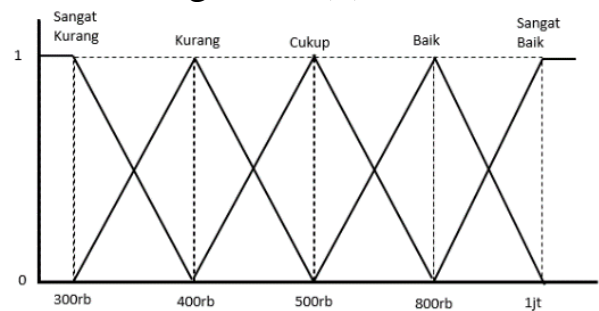

Derajat Keanggotaan Sangat Kurang:

$\mu$ Pjaminan s. kurang $[X]$

$$
=\left\{\begin{array}{c}
\frac{400.000-x}{1} ; x \leq 300.000 \\
0 ; 00.000-300.000 ; x \geq 400.000
\end{array}\right.
$$

Derajat Keanggotaan Kurang:

$\mu$ Pjaminan kurang $[X]$

$$
=\left\{\begin{array}{c}
0 ; x \leq 300.000 \text { atau } x \geq 500.000 \\
\frac{x-300.000}{400.000-300.000} ; 300.000 \leq x \leq 400.000 \\
\frac{500.000-x}{500.000-400.000} ; 400.000 \leq x \leq 500.000
\end{array}\right.
$$

Derajat Keanggotaan Cukup: 
JURNAL NUANSA INFORMATIKA

Volume 14 Nomor 1, Januari 2020

$\mu$ Pjaminan Cukup $[X]$
$=\left\{\begin{array}{l}0, x \leq 400.000 \text { atau } x \geq 800.000 \\ \frac{x-400.000}{500.000-400.000} ; 400.000 \leq x \leq 500.000 \\ \frac{800.000-x}{800.000-500.000} ; 500.000 \leq x \leq 800.000\end{array}\right.$

Derajat Keanggotaan Baik:

$\mu$ Pjaminan Baik $[X]$

$=\left\{\begin{array}{c}0 ; x \leq 500.000 \text { atau } x \geq 1000.000 \\ \frac{x-500.000}{800.000-500.000} ; 500.000 \leq x \leq 800.000 \\ \frac{1000.000-x}{1000.000-800.000} ; 800.000 \leq x \leq 1000.000\end{array}\right.$

Derajat Keanggotaan Sangat Baik:

$\mu$ Pjaminan SangatBaik $[X]$

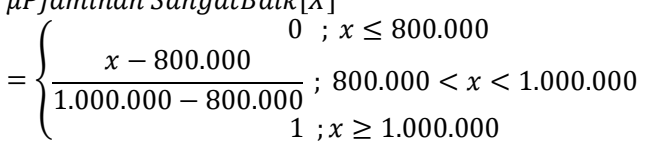

Nilai Keanggotaan Penghasilan Abdul Azis Agung Riyadi:

a. Phasil skurang $(55.000 .000)=0$

b. Phasil kurang $(55.000 .000)=0$

c. Phasil Cukup $(55.000 .000)=0$

d. Phasil Baik(55.000.000) $=0$

e. Phail SangatBaik(55.000.000) $=$ 1 ;

\section{Pinjaman}

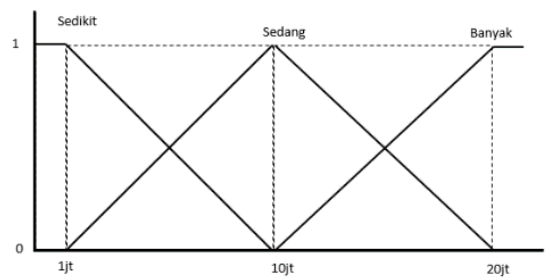

Derajat Keanggotaan sedikit:

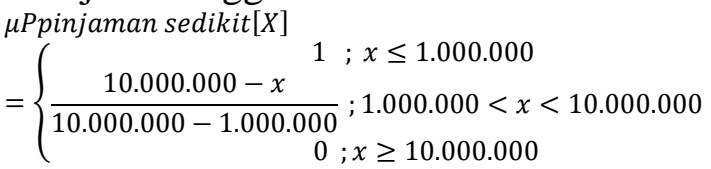

Derajat Keanggotaan sedang:

$\mu$ Ppinjaman sedang $[X]$

$=\left\{\begin{array}{c}0 ; x \leq 1.000 .000 \text { atau } x \geq 10.000 .000 \\ \frac{x-1.000 .000}{10.000 .000-1.000 .000} ; 1.000 .000 \leq x \leq 10.000 .000 \\ \frac{20.000 .000-x}{20.000 .000-10.000 .000} ; 10.000 .000 \leq x \leq 20.000 .000\end{array}\right.$

Derajat Keanggotaan Banyak:

$\mu$ Ppinjaman SangatBaik $[X]$

$=\left\{\begin{array}{c}\frac{x-10.000 .000}{0} ; x \leq 10.000 .000 \\ \frac{20.000 .000-10.000 .000}{1} ; 10.000 .000<x<20.000 .000 \\ \text { ( } 20.000 .000\end{array}\right.$
p-ISSN : 1858-3911, e-ISSN : 2614-5405

https://journal.uniku.ac.id/index.php/ilkom

\section{B. Inferensi}

Sistem inferensi metode fuzzy Tsukamoto adalah membentuk sebuah basis aturan dalam bentuk "sebabakibat". Langkah pertama dalam inferensi metode fuzzy Tsukamoto adalah membuat aturan fuzzy. Langkah selanjutnya, mencari nilai alpha predikat ( $\alpha$-predikat) dengan menggunakan fungsi implikasi MIN. Selanjutnya setelah mendapat nilai alpha predikat, nilai alpha predikat tersebut digunakan untuk menghitung output hasil inferensi dari setiap aturan yang berbentuk nilai $\mathrm{z}$

$$
\begin{aligned}
& \text { Nilai } Z_{1}=(10.000 .000-z) / \\
& (9.000 .000)=0 \\
& =10.000 .000 \\
& =\min (0 ; 0 ; 0)
\end{aligned}
$$

[R2] : $\quad \alpha$-predikat $2 \quad=$ min ( $\mu$ Penghasilan s. kurang $\cap$ $\mu$ Usaha Kurang $\cap$ $\mu$ Jaminan kurang )

$=\min (0 ; 0 ; 0)$

$=0$

Nilai $Z_{2}=(10.000 .000-z) /$
$(9.000 .000)=0$
$=10.000 .000$ [R3] : $\alpha$-predikat $3:=$ min ( $\mu$ Penghasilan s. kurang $\cap$ $\mu$ Usaha Kurang $\cap \mu$ Jaminan cukup ) $=\min (0 ; 0 ; 0)$

$=0$

Nilai $Z_{3}=(10.000 .000-\mathrm{z}) /$
$(9.000 .000)=0$
$=10.000 .000$ Lanjutkan menghitung nilai a-predikat dan z hingga aturan terakhir.

Mencari nilai $\alpha$-predikat dan nilai z dari setiap aturan

[R1] : $\quad \alpha$-predikat 1 = min ( $\mu$ Penghasilan s. kurang $\cap$ $\mu$ Usaha Kurang $\cap$ $\mu$ Jaminan s. kurang )

\section{c. Defuzzyfikasi}


Setelah di dapatkan nilai $\alpha$-predikat dan $\mathrm{z}$ dari setiap aturan, langkah selanjutnya adalah mencari nilai output. Pada metode fuzzy tsukamoto untuk mencari nilai output menggunakan metode Defuzzy weighted average atau rata-rata terbobot. Adapun cara menghitungnya:

$$
\begin{aligned}
& \mathrm{Z}=\frac{\sum \alpha-\text { pred } * \mathrm{Z}}{\sum \alpha-\text { pred }} \\
& \mathrm{Z}= \\
& \mathrm{Z}=17.812 .500
\end{aligned}
$$

Jadi pinjaman yang diberikan adalah 17.812.500

Hasil pada aplikasi adalah sebagai berikut:

Hasil Rekomendasi : Rp 17.812.500

\section{Kesimpulan Dan Saran}

\subsection{Kesimpulan}

Sistem pendukung keputusan yang diimplementasi kan ke dalam sebuah Aplikasi yang telah dibuat ditujukan agar dapat menyelesaikan permasalahanpermasalahan perusahaan, sehingga akhirnya dapat ditarik kesimpulan sebagai berikut:

1. Dengan adanya perancangan aplikasi sistem pendukung keputusan ini dapat memudahkan kepala cabang dalam pengambilan keputusan pemberian kredit dan kelayakan pada nasabah.

2. Aplikasi ini juga untuk membantu keputusan yang cepat dan keakuratan data nasabah yang selalu tersedia dalam menentukan kriteria kelayakan dalam engajuan kredit, informasi tersebut juga dapat dilihat pada laporan.

3. Adanya Databse dapat membantu kesedian data dan kecepatan data baik dalam pencarian atau penyajian informasi.

\subsection{Saran}

Dari segi analisa yang telah dibuat, masih terdapat beberapa kekurangan untuk menyempurnakan perangkat lunak ini, berikut adalah saran untuk pengembangan lebih lanjut, diantaranya:

1. Penambahan fitur-fitur pada aplikasi, seperti konfirmasi lupa password dll

2. Dapat terkoneksi ke kantor pusat sehingga perangkat lunak ini bisa dipantau oleh manager pusat.

\section{Daftar Pustaka}

[1]. Turban. dkk, Decision Support System and Intelligent System (Sistem Pendukung Keputusan dan Sistem Cerdas), Yogyakarta: Andi, 2005.

[2]. Jusuf, J. (2014). Analisis Kredit Untuk Account Officer. Jakarta: PT. Gramedia.

[3]. Rudianto. (2006). Akuntansi Koperasi.Jakarta: Grafindo.

[4]. H. P. Sri Kusumadewi, Aplikasi Logika Fuzzy untuk Pendukung Keputusan Edisi 2, Yogyakarta: Graha Ilmu, 2010 